Int. J. Electrochem. Sci., 11 (2016) $8571-8580$

\title{
Effect of Electrolyte Composition on Zn Electrode in Weak Acidic Aqueous Electrolyte
}

\author{
Zhuan Hu, Yongli Li, Jingyu Gu, Jinqing Kan ${ }^{*}$ \\ School of Chemistry and Chemical Engineering, Yangzhou University, Yangzhou, 225002, China \\ "E-mail: XX-YY
}

doi: $10.20964 / 2016.10 .21$

Received: 8 July 2016 / Accepted: 16 August 2016 / Published: 6 September 2016

\begin{abstract}
The electrochemical behavior of zinc and polyaniline (PANI) obtained by the oxidative polymerization of aniline in $1.0 \mathrm{M}$ aqueous $\mathrm{HCl}$ by $\left(\mathrm{NH}_{4}\right)_{2} \mathrm{~S}_{2} \mathrm{O}_{8}$ were investigated in $\mathrm{ZnCl}_{2}+\mathrm{NH}_{4} \mathrm{Cl}$ (chloride electrolyte), $\left(\mathrm{NH}_{4}\right)_{2} \mathrm{SO}_{4}+\mathrm{ZnSO}_{4}$ (sulfuric acid electrolyte), and $\left(\mathrm{NH}_{4}\right)_{2} \mathrm{SO}_{4}+\mathrm{ZnSO}_{4}+\left(\mathrm{CH}_{3} \mathrm{COO}\right)_{2} \mathrm{~Pb}$ ( acetic acid electrolyte) with the addition of Na-citrate and Na-malonate. Compared with sulfuric acid electrolyte and acetic acid electrolyte, zinc electrode shows the minimum of charge transfer resistance $\left(\mathrm{R}_{\mathrm{ct}}\right)$ and lower corrosion current densities, and polyaniline (PANI) keep high electrochemical activity in the chloride electrolyte at $\mathrm{pH}$ 4.0. The formation of zinc dendrite and the hydrogen evolution of the zinc electrode were suppressed in chloride electrolyte. The potentials were limited to $1.5 \mathrm{~V}$ for charge and to $0.7 \mathrm{~V}$ for discharge at $50 \mathrm{~mA} \mathrm{~g}^{-1}$, obtained the initial discharge specific capacity of $109.5 \mathrm{mAh}$ $\mathrm{g}^{-1}$, the columbic efficiency remained at around $100 \%$ after 1000 times charge-discharge cycles.
\end{abstract}

Keywords: zinc, polyaniline, dendrites, aqueous electrolyte, rechargeable batteries

\section{$\underline{\text { FULL TEXT }}$}

(C) 2016 The Authors. Published by ESG (www.electrochemsci.org). This article is an open access article distributed under the terms and conditions of the Creative Commons Attribution license (http://creativecommons.org/licenses/by/4.0/). 